\title{
EMPLOYABILITY SKILLS FOR ENTRY LEVEL WORKERS: A CONTENT ANALYSIS OF JOB ADVERTISEMENTS IN INDONESIA
}

\author{
Suarta, I M. ${ }^{1}$, Suwintana, I K. ${ }^{2}$, Fajar Pranadi Sudana, I G. P. ${ }^{3}$, \& Dessy Hariyanti, N K, ${ }^{4}$ \\ ${ }^{1,2}$ Department of Accounting, \\ Politeknik Negeri Bali, Indonesia \\ ${ }^{3}$ Department of Tourism, \\ Politeknik Negeri Bali, Indonesia \\ ${ }^{4}$ Department of Business, \\ Administration Politeknik Negeri Bali, Indonesia
}

Correspondence author email: madesuarta@pnb.ac.id

Received July $15^{\text {th }}$, 2018; Accepted November $11^{\text {th }}, 2018$

\begin{abstract}
The changing world of work is creating new challenges for employers and employees. Employers expect new workers to have a broader range of competencies and ability, strong job specific skills and employability skills. Workers entry skills that are demanded by employers may be influenced by many factors including nature of work and culture of society. The objectives of this study were to examine the labour market demand on skills as typically highlighted in job advertisements in Indonesia, and to develop a conceptual framework for employability skills. The research was conducted using content analysis method, a commonly used method in studies of job advertisements. The content analysis of job advertisements is used to identify a wide range of employability skills needed by today's labour market. The job advertisements were collected from major newspapers (published daily) that are circulated nation-wide, during February to July 2017. There are 57 job advertisements analysed. In this research, employability skills framework refer to a set of generic skills and personal attributes. The research identified 272 key terms for employability skills requirements, consisting of 191 key terms for generic skill and 81 key terms for personal attributes. In most job advertisements, employers place highest value on employability skills and lowest value on academic qualifications. Communication skills, self management skills, teamwork skills, creativity and innovation skills, and problem-solving skills are the top five of the generic skills most frequently requested in the job advertisements. Personal attributes are personal characteristics based on behaviors and attitudes that can not be separated with generic skills, including: honesty, independence, accuracy, appearance, ethics and behaviors, openness, and other characters.
\end{abstract}

Keywords: Employability skills; advertisement analysis; personal attributes; entry level worker; content analysis DOI: https://10.30880/jtet.2018.10.02.005 


\section{INTRODUCTION}

The competitive nature of the workforce has placed greater demand on graduate employability skills. Regardless of the specific job skills possessed by graduates, employers have a certain view that when entering the labour market, they are deficient in communication skills, teamwork skills, and decisionmaking skills (OECD, 2013; Jagannathan \& Geronimo, 2013; Aring, 2015). Workers are nowadays expected to have additional set of skills besides the occupational related technical skills. A number of skills and attributes, also called employability skills, are required by graduates to meet the eligibility criteria of prospective employers typically highlighted in job advertisements. Understanding employers' needs, as reflected in these advertisements can help in the preparations of future workers.

Skill mismatch is an important issue to address for the $21^{\text {st }}$ century workplace. There are emerging skill requirements associated with regional integration, structural change and new production patterns from agriculture to higher-value added industrial and services sectors. Future jobs will require workers that have strong core work skills and a set of employability skills. Some reports mention employability skills to be an indispensable skill in entering the world of work, in addition to specific job skills in the field of occupational professions (CBI, 2013; OECD, 2016). The importance and relevance of employability skills are now recognized not only by professional industry bodies, but also by educational institutions especially higher vocational education and training.

Identifying skills required by the different professions and industries are important for the vocational higher education institution to ensure that their curriculum remains relevant and up to date, thereby resulting in high-performing graduates. Employability studies clearly demonstrate that employers place highest value for generic skills and lowest value on academic reputation (Finch, et al., 2013; Abayadeera \& Watty, 2016). Having the ability to communicate, work with other people, solve problems, use analytical and critical thinking, and be a continuous learner are some of the employability skill attributes required of graduates when entering the world of work (Low, et al., 2016). In other words, the current workforce not only requires graduates with high performance in specific skills and knowledge, but also equipped with a number of generic skills and attributes.

The higher education system in Indonesia places polytechnics as a vocational higher education institution, which aims to prepare graduates to have job skills. According to Shivoro, et al. (2017), enhancing graduate employability is fundamental to higher education institutions' role of producing human capital that is capable of performing competitively in the contemporary labour market. Therefore, the vocational education curriculum needs to be developed in order to anticipate the needs of job skills in the industry. The process of curriculum development can be informed by seeking the views of stakeholders, including employers, academics, students and recent graduates, about the skills, attributes and personal characteristics required by various professions (Messum, et al., 2016). Based on this view, this paper discusses the initial stages of curriculum development that is the job skill needs analysis required by the industry through the content analysis of job advertisements.

Job advertisements analysis method is useful in identifying a wide range of skills needed by today's world of work. Several studies using the job advertisement analysis method have been done by researchers. The results showed that this method is a versatile way of identifying current skills required by various levels and professions, as well as to analyse the labour market trends (Ayalew, et al., 2011; Harper, 2012; Kureková, et al., 2015; Dunbar, et al., 2016). These skill and attributes can be an initial indicator of potential job applicants. In addition, these skills indicators are also useful in developing vocational education curriculum. 
The purpose of this research is to determine the labour market demand on employability skills as shown in job advertisements. A number of generic skill key terms and personal attributes are also identified, to develop a conceptual framework of employability skills required by prospective employers. The analysis of job advertisements for current industry skill requirements may provide important information to curriculum developers. Job advertisements aptly represent the skills and qualities that employers are looking for because the skills listed in the advertisements are carefully chosen to suit the positions being advertised. The employability skills conceptual framework is expected to be useful in guiding the development of a vocational higher education curriculum.

\section{REVIEW OF LITERATURE}

The review of literature is aimed at synthesising information on employability skills definitions, employability frameworks and employability skills demanded by employers.

\subsection{The basic concept of employability skills}

The term 'employability' has been used for many years in the context of debates about employment and labour markets. Employability skills have gained prominence of late because of the changing world of work. Employability relates to the ability to be in employment, the set of characteristics that increase the chances of an individual being in work (Belt, et al., 2010). Employability skills was used interchangeably with other terms such as generic skills, soft skills, transferable skills, non-technical skills, core skills, key skills, essential skills, and $21^{\text {st }}$ century skills (NCVER, 2003).

There are many definitions of employability skills, some of which are here discussed. Overtoom (2000), defines employability skills as “...transferable core skill groups that represent essential functional and enabling knowledge, skills, and attitudes required by the $21^{\text {st }}$ century workplace. They are necessary for career success at all levels of employment and for all levels of education”. A report from the Business Council of Australia and the Australian Chamber of Commerce and Industry (BCA/ACCI), defines employability skills as skills required not only to gain employment, but also to progress within an enterprise so as to achieve one's potential and contribute successfully to enterprise strategic directions (DEST, 2002). The Enhancing Student Employability Co-ordination Team (ESECT) defines employability skills a set of achievements - skills, understandings and personal attributes - that makes graduates more likely to gain employment and be successful in their chosen occupations, which benefits themselves, the workforce, the community and the economy (Yorke, 2006). From the various definitions, it can be concluded that employability skills are important to graduates in entering the workforce and to pursue careers in the world of work. Thus, the mastery of knowledge and job-specific or occupational skills, does not guarantee the graduate's success in the workplace. The changing nature of today's employment expects the workers to operate independently in roles that require problem-solving and decision-making skills, improving collaboration and teamwork; and employers need creative, flexible workers who have a broad range of communication and interpersonal skills.

\subsection{The employability skills framework}

Many countries have developed conceptual employability skills framework that have been used as a reference by researchers. The BCA/ACCI in 2002 conducted a comprehensive study of the skills that many workers need in order to succeed in their careers. The results of this study are outlined in Employability skills for the future, which identifies a number of personal attributes required for today's employees with eight skill groups to describe and define employability skills. The eight skill groupings are: communication skills, team work skills, problem-solving skills, initiative and enterprise skills, planning and organizing skills, self-management skills, learning skills, and technology skills (DEST, 2002). 
The Higher Education Academy (HEA) conducts a study of employability skills in the United Kingdom, and offers a wide range of perspectives on graduate's employability skills requirements. In the Learning and Employability Series documents, employability skills is defined as "a set of skills, knowledge and personal attributes that make an individual more likely to gain employment and be successful in their chosen occupations, which benefits themselves, the workforce, the community and the economy" (Yorke \& Knight, 2006). The HEA employability skills framework consists of personal qualities, core skills, and process skills. Each skill groups made up of a number of aspects.

From the ASEAN perspective, UNESCO Bangkok conducted a study on graduate employability of universities in selected ASEAN countries to develop their employability framework. The main findings of the employability framework refers to a wide range of attributes and competencies that enable the job seekers to gain and maintain employment such as, but not limited to, the following: communication skills; logical, analytical and problem solving skills; personality, confidence, and integrity; flexibility and adaptability; innovation and creativity; and team spirit (UNESCO Bangkok, 2012). The next UNESCO Bangkok report (2015) concluded UNESCO Framework for Transversal Competencies consisting of five broad domains of skills, competencies, values and/or attributes. These are: critical and innovative thinking; inter-personal skills; intra-personal skills; global citizenship; and media and information literacy. Each domain of transversal competencies consists of a number of skill attributes.

In the author's perspective, employability skills are defined as non-technical or non-specific skills which are very important for individual to acquire and keep a job. Most importantly, these skills are not job specific, but are skills which cut horizontally across all industries and vertically across all jobs at all levels. In our conceptual, employability skills consist of a set of generic skills and personal attributes, used in tandem with the knowledge and specific skills in the workplace.

\subsection{The employers' demands on employability skills}

Many studies have been conducted to find out the employer's desire about the employability skills attributes that must be possessed by job seekers. Olawale (2015) conducted the study to analyse job advertisements in the field of construction project and found that the most sought after employability skills demanded by employers is team-working ability. Furthermore, communication skills both oral and written, flexibility, problem solving skills, initiative and time management emerged as the skills required in the construction field job advertisements. Dunbar, et al. (2016) investigated the emphasis placed on technical and soft skills by prospective employers for accounting positions and graduate accounting positions in particular. The study highlights that soft skills dominate technical skills as requirements by employers. Communication skill was the most frequently requested soft skill in the job advertisements. Closely followed by interpersonal and team work skills. Previously, Warwick \& Howard (2015) also found the communication skills, analytical skills, problem solving, interpersonal skills, teamwork, self-management, and critical analysis as a high ranking skills required by accounting graduates in entering the world of work.

Messum, et al. (2016) presents a qualitative integrative review of studies looking at employability skills through the use of content analysis of job vacancy advertisements. The analysis finds communication skills were the most commonly advertised skill requirement followed by teamwork skills, job specific skills, experience, interpersonal skills, organizational skills, leadership, personal qualities, creativity and innovation, analytical skills, problem solving, and work independently. The employer survey conducted by Sarkar, et al. (2016) aims to explore employers' views of employability skills in the current and future work climate. Flexibility or adaptability, problem solving skills, analytical and critical thinking skills, initiative, and team working skills are found as the top five important graduate skills and capabilities in current and future situation. 
McMurray, et al. (2016) publish the paper on research carried out with employers to determine demand for graduate business and management skills in the Scottish workforce. The research used an employer questionnaire distributed through various methods. The research found that the factors which were most important to employers when recruiting graduates were: personal attitude, employability skills, relevant work experience, and degree result. The ten most important transferable skills to employers when recruiting graduates were: trustworthiness, reliability, motivation, communication skills, willingness to learn, commitment, interpersonal skills, adaptability, teamwork, and initiative.

\section{RESEARCH METHODS}

This study uses a qualitative approach, carried out by a non-participant observation method. The intended observation is to find the employability skills attributes as shown in job advertisements. Through this method, data collection on employability skills attributes that are required in job advertisements is done by naturalistic observation of documented information, without manipulating the facts.

The job advertisements were collected from major newspapers (published daily) that are circulated nation-wide in Indonesia. This data was collected for all kinds of entry level positions, with maximum three year work experiences. During February to July 2017, there are 57 job advertisements have been collected. The data was input into an excel spreadsheet for the purpose of conducting the analysis. The data recorded includes: the industry type, job title, academic requirements, knowledge and specific skills, employability skills attribute, and work experience. During collected the data, we also conducted an indepth focus group discussion to determine an overview of employability skills framework. The authors use the term employability skills as referring to a set of generic skills and personal attributes.

The data were analysed using content analysis method, a commonly used method in studies of job advertisements. Content analysis refers to a family of procedures for the systematic, replicable analysis of texts, and provides a structured way of analyzing data that are typically open-ended and relatively unstructured (Rose, et al., 2015). It involves the classification of parts of a text through the application of a structured, systematic coding scheme from which conclusions can be drawn about the message content. By clearly specifying the coding and other procedures content analysis is replicable in the sense that other researchers could reproduce the study. Different studies using content analysis for analyzing job adverts (Ayalew, et al., 2011; Dunbar et al., 2016; Messum, et al., 2016) have indicated that content analysis helped to identify skills in demand at present and identify shifts in the patterns of skill demands over time.

As conducted by Dunbar et al. (2016), the grouping attributes was undertaken manually by examining a sample of the source data from which the concepts were drawn, to determine the likely meaning of the concept. Based on data tabulated using excel spreadsheets, the analysis started by identifying words, groups of words, phrases or key terms that are in accordance with the concept of employability skills. The identification focused on the definition of employability skills which include generic skills and personal attributes. The next step is grouping words, groups of words, phrases or key terms based on similarity of meaning through the application of a structured, systematic coding scheme from which conclusions can be drawn about the message content. When something came up that was unexpected another category would then be created. Although variation in source data was expected, if this was sufficiently high to make identification of the most appropriate group difficult then the concept was placed in the miscellaneous group. The final analysis involves the application of descriptive statistical techniques, such as frequency counts, summary findings according to the conceptual framework of employability skills, and presenting data in graphical form. 


\section{RESEARCH RESULTS}

\subsection{Job advertisement profile}

The research focus was too observed and recorded the attributes of employability skills that become the requirements in job advertisements. The data source is the job advertisements from multi-national companies that are published in national newspapers. The analysis of job advertisements focused on entry level worker positions, graduated from diploma and undergraduate study programme, with no more than 3 year work experience. There are 73 job positions that meet these criteria of the 57 job advertisements analysed.

In general, employers do not emphasize academic requirements marked by GPA. Only 2 positions (2.7\%) require the need for GPA. Moreover, the employer is more likely to assess job seekers based on the skills they possess, whether it's specific or employability skills. The research identified 103 key terms of specific skills and 272 key terms of general skills requirements. Employability skills consist of generic skills and personal attributes. There are 191 key terms including generic skill groups and 81 key terms including personal attribute groups.

\subsection{Employability skills profile}

Based on the literature review and in-depth focus group discussion, we formulated seven types of skills that are included in the generic skill groups, namely: communication skills, teamwork skills, problem solving skills, creativity and inovation skills, leadership skills, self management skills, and learning skills. Table 1 shows key terms that have been aligned based on similarity of meaning and become a characteristic of each type of generic skills.

Table 1: The key terms of generic skills

\begin{tabular}{ll}
\hline Generic Skill Group & \multicolumn{1}{c}{ Key Terms in the Job Advertisements } \\
\hline \multirow{2}{*}{ Communication skills } & $\begin{array}{l}\text { Customer oriented, guest interaction, interpersonal, ability to } \\
\text { communicate, ability to coordinate, express opinions / ideas, the ability to } \\
\text { negotiate, presentation, the ability to build relationships. }\end{array}$
\end{tabular}

Able to transform into business opportunities, active and challenging person, being pro-active, creative ability, driven to success, energetic, hard

Creativity and innovation skills worker, have entrepreneurial spirit and get things done, have strong business sense, highly motivated, initiative, creative \& innovative, selfmotivated.

High dedication, integrity, good leadership, high integrity and loyalty,

Leadership skills leadership skills, have leadership spirit, showing integrity, strong leadership quality.

Learning skills Ability to multi-task, adapting to the culture of the company, enthusiastic, fast learner, willingness to develop or learn endlessly, love challenges at work, passion to learn.

Problem-solving skills Analytical skill, responsible for the decision, critical thinking, problem solving skill, smart working, strong analytical, think smart, thinking skill.

Able to work under pressure, able to work with target, achievement orientation, working under pressure, target oriented, willing to work hard,

Self-management skills can work efficiently, deliver high quality work on schedule, discipline, good performance, result oriented, self-driven, self-starter with an inquiring mind, resistant to job pressures, target oriented, willing to work under presure. 
We found 191 key terms as in Table 1 of the 57 job advertisements analysed. That is, each job advertisement requires 3 to 4 generic skills attributes. Figure 1 presented the graphic percentage of attributes or key terms in each group of generic skills.

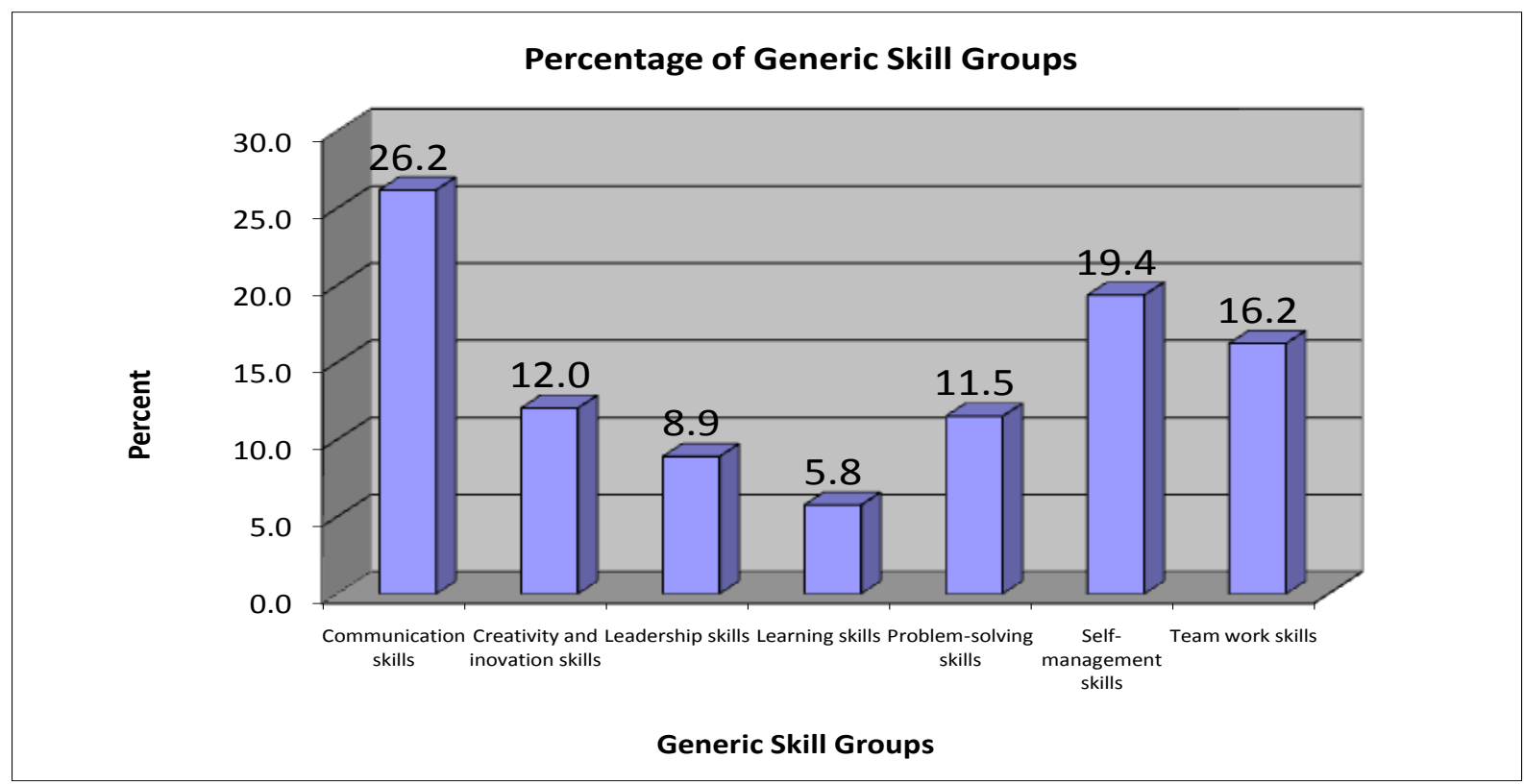

Figure 1: Percentage frequency of key terms according to generic skills groups

Based on focus group discussion (FGD), authors concluded that personal attributes are personal characteristics that can not be separated with generic skills, consisting of: honesty, accuracy, independence, appearance, openness, ethics and behavior, and others character. Table 2 presents a number of key terms that have been aligned based on similarity of meaning and become an identifier of each group of personal attributes.

Table 2: The key terms of personal attribute

\begin{tabular}{ll}
\hline Personal Attribute Group & \multicolumn{1}{c}{ Key Terms in the Job Advertisements } \\
\hline Honesty & Personality honest, honest \\
\hline Accuracy & $\begin{array}{l}\text { Accurate, attention to detail, tidiness in document filling, thoroughness, thorough } \\
\text { related numbers and documentation }\end{array}$ \\
\hline Independence & $\begin{array}{l}\text { Able to work individually, be able to work independently, can work individually, } \\
\text { independent, able to work independently, work with limited supervision }\end{array}$ \\
\hline Appearance & $\begin{array}{l}\text { Aggressive, attractive, attractive appearance, good looking, supple, pleasant } \\
\text { personality, neat. }\end{array}$ \\
\hline Openness & Open minded, broad-minded, flexibility and initiative, adaptability \\
\hline Ethics and behavior & $\begin{array}{l}\text { Ethics and good attitude, good working attitude, having good attitude, } \\
\text { persuasiveness, superior work ethics }\end{array}$ \\
\hline Others character & $\begin{array}{l}\text { Smart, deft, dynamic, excellent/good personality, loyal, most importantly } \\
\text { consistent, confidence, assertive }\end{array}$ \\
\hline
\end{tabular}


We found 81 key terms about personal attributes on 57 job advertisements. Figure 2 presents the percentage occurrences of each team according to group of personal attributes.

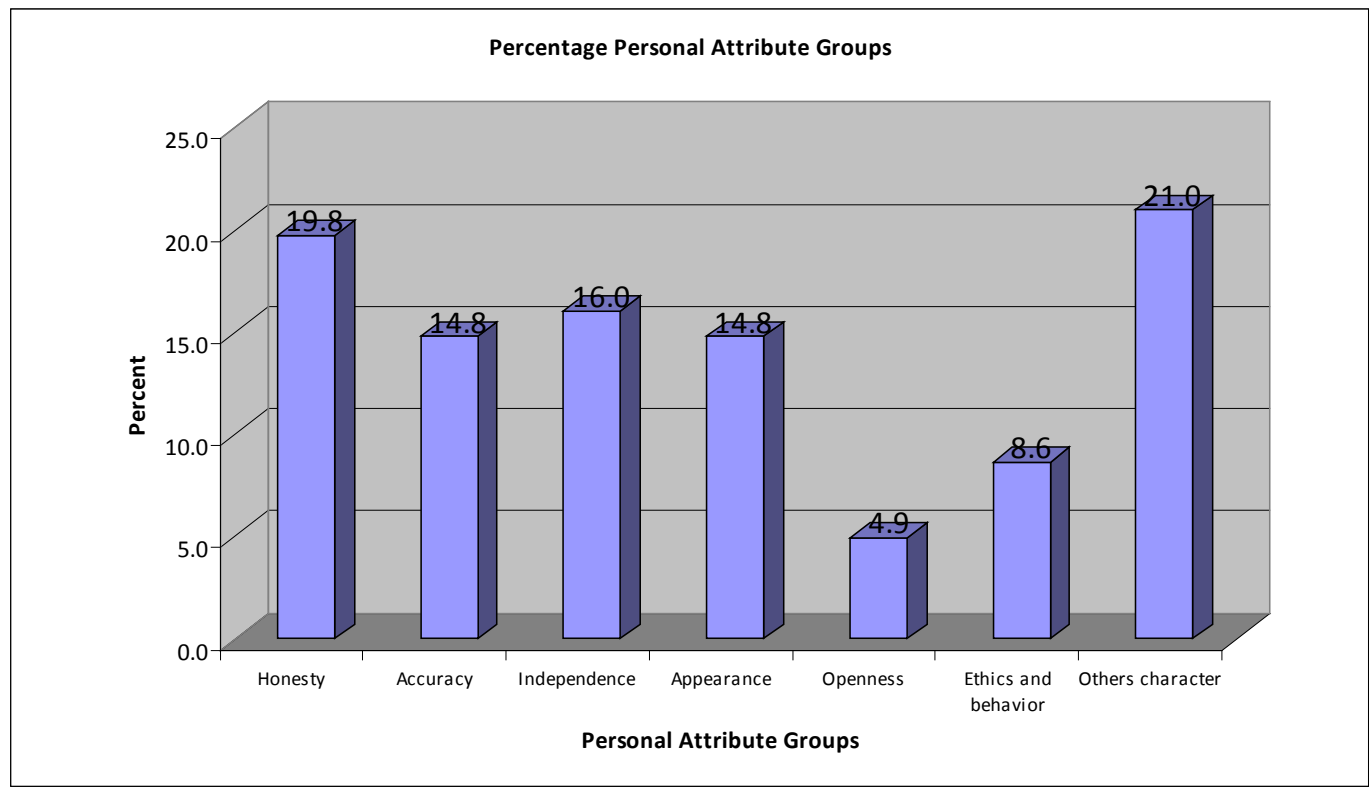

Figure 2: Percentage frequencies of key terms according to personal attribute groups.

\section{DISCUSSION}

The employability of graduates is becoming an increasingly important topic within higher education and professional industry bodies. Possess of knowledge and technical skills, does not guarantee the graduate's success in the workplace. Employers place highest value for employability skills and lowest value on academic reputation. In this study, we analysed 73 job positions. In general, employers do not emphasize academic requirements marked by GPA. Only $2.7 \%$ of job positions require the GPA. Moreover, the employer is more likely to assess job seekers based on the skills they possess, whether it's specific or employability skills. The study's results also showed that there are 103 (27.5\%) key terms of specific skills and 272 (72.5\%) key terms of general skills requirements in the job advertisements analysed. The findings of this study are in line with previous studies (Finch, et al., 2013; Abayadeera \& Watty, 2016; Low, et al., 2016) which suggest that employers in recruiting new workers are more concerned with the acquisition of employability skills than academic qualifications. These results indicate that occupation-specific skills are no longer sufficient for a worker to enter the workforce.

Identifying employability skills are important for the vocational higher education institution to ensure that the curriculum relevant and up to date. Employability skills framework refer to a set of generic skills and personal attributes used in tandem with the knowledge and specific skills in the workplace. The top five generic skills group most frequently requested in the job advertisements is: communication skills (26.2\%), self-management skills (19.4\%), teamwork skills (16.2\%), creativity and innovation skills (12.0\%), problem-solving skills (11.5\%). The study's findings are in line with previous studies (Singh, et al., 2013; Olawale, 2015; Warwick \& Howard, 2015).

Communication skills relate to one's ability in the context of speaking, listening, writing and reading, and important part of human interaction. Communication skills play a vital role in the life of professionals (Mahajan, 2015). Morreale, et al. (2017) concluded that communication, and specifically oral communication, is critical to students' future personal and professional success. Key terms of 
communication skills that are found in job advertisements, such as: communication when negotiating and interacting with guests, ability to communicate, express opinions / ideas, the ability to negotiate, presentation, and the ability to build relationships.

Self-management skills are those characteristics that help an employee to feel and be more productive in the workplace. Self-management at workplace is about planning, organizing and controlling the employee's own work activities (Renn, et al., 2011). The findings study of Palvalin, et al. (2017) show that self-management practices have a larger impact on the quality and quantity of individual output and the quantity of team output. Self-management skills help an employee communicate and interact efficiently with fellow workers, supervisors, and even customers. They also help employees make good decisions and improve time management. Key terms of self-management skills found in job advertisements involves: able to work under pressure, able to work with target, achievement orientation, willing to work hard, can work efficiently, deliver high quality work on schedule, self-driven, and self-starter. Improving selfmanagement skills is key to increase all productivity dimensions and in particular the quality of the output.

Teamwork is a cooperative process that allows ordinary people to achieve extraordinary results. Key terms of teamwork in job advertisements involves: ability to work in a team, cooperative, able to work together in teams, motivated team player, strong team work skills, team player, and team work. Teamwork is a key requirement in most occupations and an essential part of workplace success. Employers are seeking to recruit individuals who pay due attention to relations with peers and superiors. Employers noted the ability to work with others effectively is an important work-readiness skill (Griffin \& Annulis, 2013).

Creativity and innovation in the workplace have become increasingly important determinants of organizational performance, success, and longer-term survival. Creativity and innovation at work are the process, outcomes, and products of attempts to develop and introduce new and improved ways of doing things. The creativity stage of this process refers to idea generation, and innovation to the subsequent stage of implementing ideas toward better procedures, practices, or products (Anderson, et al., 2014). Creative thinking is one of the professional skills that will be most sought-after by future employers. One of the biggest predictions is that the future global economy will be made up mostly of creative and innovative output. Key terms of creativity and innovation skills found in job advertisements involves: able to transform into business opportunities, active and challenging person, being pro-active, creative ability, driven to success, have entrepreneurial spirit and get things done, have strong business sense, highly motivated, initiative.

Problem solving and decision-making are important skills for business and life. In order to compete, job seekers in the $21^{\text {st }}$ century must be able to find logical solutions and give effective decisions of the problems. Problem solving skills are found to contribute to productive outcomes. Problem-solving competence is an essential component of the skills required to perform interpersonal and non-routine analytic tasks successfully (OECD, 2014). Problem solving and decision-making are sometimes used interchangeably. Key terms of problem solving skills that are found in job advertisements: analytical skill, responsible for the decision, critical thinking, problem solving skill, smart working, think smart, thinking skill.

In addition to generic skills, employability skills are also composed by a number of personal attributes. The personal attributes are personal characteristics that can not be separated with generic skills. In the document of employability skills for the future (DEST, 2002), personal attributes used to describe a set of non-skill based on behaviors and attitudes that employers felt were as important as the employability skills and other technical or job specific skills, include: loyalty, commitment, honesty and integrity, enthusiasm, reliability, personal presentation, commonsense, positive self-esteem, sense of humor, balanced attitude to work and home life, ability to deal with pressure, motivation, adaptability. 
In this research, author proposes personal attributes consist of: personal integrity and honesty, accuracy and attention to detail, able to work independently and limited supervision, pleasant personality and appearance, openness and broad-minded, ethics and behavior, and others character. The study found 81 key words or personal attribute phrases as a requirement in the job advertisements. The personal attributes most frequently requested in the job advertisements are: honesty, independence, accuracy and appearance. Closely followed by ethics and behavior, openness, and others character. The findings of the study is parallel to McMurray, et al. (2016) that personal attitudes as an important factor for employers when hiring graduates. Other research also found attributes such as integrity and professional ethics (Singh, et al., 2013; Rasul, et al., 2013), flexibility and initiative (Olawale, 2015), flexibility or adaptability (Sarkar, et al., 2016) are key terms of personal attributes that are important to jobseekers. Research conducted by Plantilla (2017) found that employers considered personal qualities as extremely important for the employees to successfully perform their job. They put much premium on self-discipline, positive attitude towards work and willingness to learn as important qualities of an employee.

The results of this study indicate the importance of generic skills and personal attributes of graduates in entering the workforce. These generic skills and personal attributes should emanate to the graduates for them to be hired in their jobs. In order to reduce the skill gaps of graduates, providers of higher vocational education need to revitalize their curriculum. The higher vocational education curriculum must be able to develop student employability skills.

\section{CONCLUSION AND RECOMMENDATIONS}

Based on the findings of the study, the researcher concluded that employers expected new workers to possess a number of employability skill attributes. The employers' demand indicates that occupationspecific skills are no longer sufficient for graduates to meet the needs of today's labour markets. They prefer to hire graduates who have employability skills. In most job advertisements, employers place highest value for employability skills and lowest value on academic requirements.

Employability skills framework refer to a set of generic skills and personal attributes used in tandem with the application of knowledge and specific skills in the workplace. We proposed seven types of ability for generic skills, namely: communication skills, teamwork skills, problem solving skills, creativity and inovation skills, leadership skills, self management skills, and learning skills. Communication skills, self management skills, teamwork skills, creativity and innovation skills, and problem-solving skills are the top five of the generic skills most frequently requested in the job advertisements. Personal attributes are personal characteristics based on behaviors and attitudes that can not be separated with generic skills, consisting of: honesty, accuracy, independence, appearance, openness, ethics and behavior, and others character. The personal attributes most frequently requested in the job advertisements are: honesty, independence, accuracy and appearance.

In light of the significant findings, the researcher recommended to the higher vocational education provider to review the existing curriculum. The main focus of the review is to provide space and enrich the curricular programme in developing student employability skills. For the future research, we recommended to conduct a cross-industry survey, focusing on the identification of important employability skills needed for successful school to work transition. This study has a number of limitations, including the number of job advertisement samples being analysed. Therefore, the scope of future study should be expanded to obtain more comprehensive job advertisements.

\section{References}

Abayadeera, N., \& Watty, K. (2016). Generic skills in accounting education in a developing country: Exploratory evidence from Sri Lanka. Asian Review of Accounting, 24(2): 149 - 170. 
Anderson N., Potočnik K., \& Zhou J. (2014). Innovation and creativity in organizations: A state-of-the-science review, prospective commentary, and guiding framework. Journal of Management, 40(5): 1297-1333. https://doi.org/10.1177/0149206314527128.

Aring, M. (2015). ASEAN Economic Community 2015 : Enhancing competitiveness and employability through skill development. Bangkok: ILO Regional Office for Asia and the Pacific.

Ayalew, Y., Mbero, Z.A., Nkgau, T.Z., Motlogelwa, P., \& Masizana-Katongo, A. (2011). Computing knowledge and skills demand: A content analysis of job adverts in Botswana. International Journal of Advanced Computer Science and Applications, 2(1): 1 - 10.

Belt, V., Drake, P., \& Chapman, K. (2010). Employability Skills: A Research and Policy Briefing. Briefing Paper Series, UK Commission for Employment and Skills. Accessed February 22, 2018, from http://www.educationandemployers.org/wp-content/uploads/2014/06/ employability-skills-policy-briefingukces.pdf

Dunbar, K., Laing, G., \& Wynder, M. (2016). A content analysis of accounting job advertisements: Skill requirements for graduates. e-Journal of Business Education \& Scholarship of Teaching, 10(1): 58 - 72.

Finch, D. F., Hamilton, L. K., Riley, B. \& Zehner, M. (2013). An exploratory study of factors affecting undergraduate employability. Education + Training, 55(7): 681-700.

Griffin, M., \& Annulis, H. (2013). Employability skills in practice: The case of manufacturing education in Mississippi. International Journal of Training and Development, 17(3): 221-232.

Harper, R. (2012). The collection and analysis of job advertisements: a review of research methodology. Library and Information Research, 36(112): 29 - 54. Available at http://www.cilipjournals.org.uk/lir

Jagannathan, S., \& Geronimo, D. (2013). Skills for Competitiveness, Jobs, and Employability in Developing AsiaPacific. Manila: Asian Development Bank.

Kureková, L.M., Beblavý, M. \& Thum-Thysen, A. (2015). Using online vacancies and web surveys to analyse the labour market: a methodological inquiry. IZA Journal of Labour Economics (2015) 4: 18. https://doi.org/10.1186/s40172-015-0034-4

Low, M., Botes, V., Dela Rue, D., \& Allen, J. (2016). Accounting employers' expectations - The ideal accounting graduates. e-Journal of Business Education \& Scholarship of Teaching, 10(1): 36-57.

Mahajan, R. (2015). The key role of communication skills in the life of professionals. IOSR Journal Of Humanities And Social Science (IOSR-JHSS), 20(12) : 36 - 39.

McMurray, S., Dutton, M. McQuaid, R.W., \& Richard, A. (2016). Employer demands from business graduates. Education + Training, 58(1): 112-132, https://doi.org/10.1108/ET-02-2014-0017

Messum, D., Wilkes, L., Peters, K., \& Jackson, D. (2016). Content analysis of vacancy advertisements for employability skills: Challenges and opportunities for informing curriculum development. Journal of Teaching and Learning for Graduate Employability, 6 (1): 72 - 86.

Morreale, S.P., Valenzano, J.M., \& Bauer, J.A. (2017). Why communication education is important: a third study on the centrality of the discipline's content and pedagogy. Communication Education, 66(4) : 402-422, DOI: 10.1080/03634523.2016.1265136

NCVER. (2003). Defining Generic Skills: At a glance. Adelaide, Australia: National Centre for Vocational Education Research (NCVER).

OECD. (2013). OECD Skills Outlook 2013: First Results from the Survey of Adult Skills. Accessed February 25, 2016, from http://skills.oecd.org/skillsoutlook.html

OECD. (2016). Enhancing employability. Accessed February 20, 2018, from http://www.oecd.org/g20/topics/employment-and-social-policy/Enhancing-Employability-G20-Report2016.pdf

OECD. (2014). PISA 2012 Results: Creative Problem Solving (Volume V) Students' Skills in Tackling Real-Life Problems. OECD Publishing. Online at https://play.google.com/books/reader?id=HC7jAwAAQBAJ\&hl=en\&pg=GBS.PA26

Olawale, Y. (2015). The employability skills provision within a construction Project Management Degree programme In: Raidén, A B and Aboagye-Nimo, E (Eds) Procs 31 Annual ARCOM Conference, 7-9 September 2015, Lincoln, UK, Association of Researchers in Construction Management, 959-968.

Overtoom, C. (2000). Employability skills: An update. ERIC Digest No. 220. Columbus, Ohio: ERIC Clearinghouse on Adult, Career, and Vocational Education. Accessed July 12, 2015, from http://www.ericdigests.org/20012/skills.htm.

Palvalin, M., Theo van der Voordt \& Tuuli Jylhä. (2017). The impact of workplaces and self-management practices on the productivity of knowledge workers. Journal of Facilities Management, 15(4): 423-438, https://doi.org/10.1108/JFM-03-2017-0010 
Plantilla, A. M. (2017). Graduates performance in the workplace: Employers' perspective. Asia Pacific Journal of Multidisciplinary Research, 5(2): 186 - 198.

Rasul, M.S., Abd Rauf, R.A., Mansor, A.N., Yasin, R.M., \& Mahamod, Z. (2013). Graduate employability for manufacturing industry. Procedia - Social and Behavioral Sciences, 102(2013): $242-250$.

Renn, R. W., Allen, D. G. \& Huning, T. M. (2011). Empirical examination of the individual-level personality-based theory of self-management failure. Journal of Organizational Behavior, 32(1): 25-43.

Rose, S., Spinks, N., \& Canhoto, A.I. (2015). Management Research: Applying the Principles. Oxford, UK: Taylor \& Francis Group Ltd.

Sarkar, M., Overton, T., Thompson, C., \& Rayner, G. (2016). Graduate employability: Views of recent science graduates and employers. International Journal of Innovation in Science and Mathematics Education, 24(3): 31-48.

Shivoro, R., Shalyefu, R.K., \& Kadhila, N. (2017). A critical analysis of universal literature on graduate employability. Journal for Studies in Humanities and Social Sciences, 6(2): 248-268.

Singh, P., Thambusamy, R., Abdullah, I.H., Ramly, A., \& Mahmud, Z. (2013). Perception differential between employers and instructors on the importance of employability skills. Procedia Social and Behavioral Sciences, 90(2013): 616 - 625 .

The Confederation of British Industry (CBI). (2013). Changing the Pace: CBI/Pearson education and skills survey 2013. Accessed February 22, from http://www.cbi.org.uk/media/2119176/education_and_skills_survey_2013.pdf

The Department of Education, Science and Training (DEST). (2002). Employability skills for the future. A Report by the Australian Chamber of Commerce and Industry (ACCI) and the Business Council of Australia (BCA) for the Department of Education, Science and Training, Canberra.

UNESCO Bangkok Office. (2012). Graduate Employability in Asia. Accessed March 21, 2013, from http://unesdoc.unesco.org/images/0021/002157/215706E.pdf

UNESCO Bangkok Office. (2015). 2013 Asia-Pacific Education Research Institutes Network (Eri-Net) Regional Study On Transversal Competencies in Education Policy \& Practice. Accessed March 12, 2016 from http://unesdoc.unesco.org/images/0023/002319/ 231907E.pdf.

Warwick, J., \& Howard, A. (2015). A note on structuring employability skills for accounting students. International Journal of Academic Research in Business and Social Sciences, 5(10): 165 - 174. DOI: 10.6007/IJARBSS/v5i10/1860.

Yorke, M. (2006). Employability in Higher Education: What it is - What it is not. York, United Kingdom: The Higher Education Academy.

Yorke, M. \& Knight, P.T. (2006). Embedding Employability into the Curriculum. York, United Kingdom: The Higher Education Academy. 